Diabetologia (1994) 37: 344-350

\title{
A novel radioligand binding assay to determine diagnostic accuracy of isoform-specific glutamic acid decarboxylase antibodies in childhood IDDM
}

\author{
C. E. Grubin ${ }^{1}$,T. Daniels ${ }^{1}$, B.Toivola ${ }^{2}$, M.Landin-Olsson ${ }^{3}$, W. A.Hagopian ${ }^{1}$, L. Li ${ }^{1}$, A. E. Karlsen ${ }^{4}$, E. Boel ${ }^{5}$, \\ B. Michelsen ${ }^{4}$, A. Lernmark ${ }^{1,6}$ \\ ${ }^{1}$ Department of Medicine, University of Washington, Seattle, Washington, USA \\ ${ }^{2}$ Department of Laboratory Medicine, University of Washington, Seattle, Washington, USA \\ ${ }^{3}$ Department of Medicine, University of Lund, Lund, Sweden \\ ${ }^{4}$ Hagedorn Research Institute, Gentofte, Denmark \\ ${ }^{5}$ Novo Nordisk A/S, Bagsvaerd, Denmark \\ ${ }^{6}$ Department of Endocrinology, Karolinska Hospital, Stockholm, Sweden
}

\begin{abstract}
Summary Insulin-dependent diabetes mellitus (IDDM) is associated with autoreactivity against GAD but the diagnostic sensitivity (positivity in disease) and specificity (negativity in health) of isoform-specific GAD antibodies have yet to be defined in assay systems suitable for screening large number of samples. One set of IDDM patient $(n=10)$ and control $(n=50)$ standard sera were used to develop quantitative antibody assays with in vitro synthesized recombinant ${ }^{35} \mathrm{~S}$ methionine-labelled GAD65 and GAD67, respectively, and protein A-Sepharose to separate free from antibody-bound ligand. Binding levels were not normally distributed $(p<0.0001)$ and therefore, the diagnostic accuracy of GAD antibodies was analysed by the ROC plots in population-based, consecutively-diagnosed, recent onset, $0-14$ year-old patients $(n=105)$, and matched, healthy control subjects $(n=157)$. The ROC
\end{abstract}

plots showed that the diagnostic sensitivity of GAD65 antibodies was $77 \%$ and the specificity $92 \%$ compared with $8 \%$ and $98 \%$, respectively for GAD67 antibodies. In the IDDM sera, GAD65 and GAD67 antibodies were concordant in 7\% (6 of 81) and GAD65 antibodies and ICA in $89 \%$ ( 72 of 81 ) without a correlation between the autoantibody levels. Autoantibodies to recombinant human islet GAD65 are specific and sensitive markers for childhood IDDM in this immunoassay with in vitro synthesized ${ }^{35} \mathrm{~S}$-methioninelabelled recombinant GAD. [Diabetologia (1994) 37: 344-350]

Key words Glutamic acid decarboxylase, receiveroperating characteristic plot, diagnostic accuracy, islet cell antibodies, autoimmunity, diabetes mellitus
Serum samples from recent onset patients with IDDM [1-3] or first degree relatives later developing this disease $[4,5]$, have been shown to immunoprecipitate a $M_{r}$ $64,000(64 \mathrm{~K})$ islet cell protein, later identified as GAD [6]. The human islet GAD was discovered to represent a new isoform, GAD65, which is coded for by a previously unidentified gene (GAD2) on chromosome

Received: 12 August 1993

and in revised form: 1 November 1993

Corresponding author: Professor Å.Lernmark, Karolinska Institute, Department of Endocrinology, Karolinska Hospital, L1:02, S-171 76 Stockholm, Sweden

Abbreviations: IDDM, insulin-dependent diabetes mellitus; GAD, glutamic acid decarboxylase; ROC, receiver-operating characteristic; ICA, islet cell antibodies; JDF, Juvenile Diabetes Foundation 10p11.3-p12 [7]. GAD65 shows $65 \%$ amino acid identity with GAD67, the isoform coded for by the GAD1 gene on chromosome 2q31 [7-9]. The molecular cloning of full-length human islet GAD65 [7] and rat islet GAD67 [10] cDNA has made it possible to demonstrate autoreactivity in diabetes to the recombinant proteins in both eukaryotic $[11,12]$ and bacterial [13] expression systems. GAD65 (but not GAD67) is expressed in human islets $[11,14]$, however, variable reactivity of patient sera has been reported [12, 13, 15-19]. GAD65 specificity of IDDM sera was first demonstrated in our immunoprecipitation assay with recombinant GAD expressed in transfected cells [12] and recently confirmed in other assays with recombinant antigens $[18,20]$. The use of different assay systems and species-specific GAD65 and GAD67 may explain the lower frequency of GAD67 antibodies in these compared to previous reports $[13,16]$. We now report the 
use of GAD65 [7, 21] and GAD67 [10] cDNA to synthesize by in vitro translation and transcription specific radioactive ligands used in a radioimmunoassay of GAD65 and GAD67 antibodies and the use of the ROC plot [22-25] to determine the diagnostic accuracy of the GAD antibody test.

\section{Subjects and methods}

\section{Patients}

Two sets of patients and control subjects were studied (Table 1). The first was used to validate the assays and represented sera obtained by plasmapheresis from 10 recent onset IDDM patients $[26,27]$ and from 50 healthy, 20-49-year-old volunteers (top panel, Table 1). The IDDM sera were the very same as those previously used to identify antibodies to the $64 \mathrm{~K}$ protein [2]. These sera have been used extensively in the Immunology of Diabetes Workshop to standardize ICA [28,29] and one of the samples is used as the worldwide standard for expression of ICA levels in JDF units [28].

The second set of subjects comprised 105 consecutively diagnosed IDDM patients and 157 age-, sex- and geographicallymatched healthy control subjects (lower panel, Table 1). These Swedish patients and control subjects have previously been described $[30,31]$ and represent $0-14$-year-olds with a IDDM incidence of 25 per 100,000 and prevalence rate of $0.15 \%$ [32].

\section{Preparation of recombinant $G A D$}

Two overlapping human islet GAD65 cDNA clones [7] were spliced [11] into a full-length expression clone, $\mathrm{pEx} 9$ in pcDNAII (Invitrogen, San Diego, Calif., USA). A full-length rat islet GAD67 cDNA clone [10] was similarly inserted into the pGEM4 vector (Promega, Madison, Wis., USA) to generate pEX12. The pEX9 plasmid DNA was linearized with XbaI and pEx12 with Hind III. Both enzymes cut in the respective $3^{\prime}$-untranslated region. After phenol:chloroform:isoamyl alcohol (50:48:2) extraction, the cDNA was precipitated in ethanol, dried and resuspended in $\mathrm{H}_{2} \mathrm{O}$. RNA was transcribed using $5 \mu \mathrm{g}$ linearized cDNA in $50 \mu \mathrm{l}$ final volume containing $40 \mathrm{U}$ SP6 polymerase (BRL, Gaithersburg, Md., USA) in transcription buffer ( $40 \mathrm{mmol} / \mathrm{l}$ Tris, $\mathrm{pH} 7.9,6 \mathrm{mmol} / 1 \mathrm{MgCl}, 2 \mathrm{mmol} / 1$ spermidine, $10 \mathrm{mmol} / \mathrm{l}$ dithiothreitol, $0.1 \mathrm{mg} / \mathrm{ml}$ bovine serum albumin $1 \mathrm{U} / \mathrm{ml}$ RNAsin) supplemented with $0.5 \mathrm{mmol} / 1$ each of ATP, CTP, and UTP, $50 \mathrm{mmol} / \mathrm{l} \mathrm{GTP}$, and $0.5 \mu \mathrm{mol} / \mathrm{l} \mathrm{m} 7 \mathrm{GpppG}$. After incubation for $60 \mathrm{~min}$ at $37^{\circ} \mathrm{C}$, an additional $50 \mu \mathrm{l}$ of transcription buffer supplemented with $0.5 \mathrm{mmol} / 1$ each of ATP, CTP, UTP and GTP was added, and the incubation continued for another $45 \mathrm{~min}$ at $37^{\circ} \mathrm{C}$. The reaction was stopped by addition of $5 \mathrm{U}$ RNase-free DNase and incubation for $15 \mathrm{~min}$ at $37^{\circ} \mathrm{C}$. RNA was phenol:chloroform:isoamyl alcohol extracted, precipitated with 0.5 volume $7.5 \mathrm{~mol}$ ammonium acetate and 2.5 volumes ethanol, and collected by centrifugation for $30 \mathrm{~min}$ at $4^{\circ} \mathrm{C}$. The precipitate was washed in $70 \%$ ethanol and resuspended in distilled $\mathrm{H}_{2} \mathrm{O}$. Denaturing agarose gel electrophoresis using 3-(Mmorpholino) propane sulphonic acid/formaldehyde, and visualization with ethidium bromide under ultraviolet light was used to check the presence of a single band of RNA.

In vitro translation was carried out with nuclease treated rabbit reticulocyte lysate (Promega) according to the manufacturer's instructions. Briefly, $2 \mu \mathrm{g}$ in vitro synthesized mRNA was heated at $67^{\circ} \mathrm{C}$ for $10 \mathrm{~min}$ and immediately put on ice prior to the addition of translation mixture and $5 \mu \mathrm{Ci}{ }^{35} \mathrm{~S}$-methionine (Amersham Int., Amersham, Bucks., UK; > $1000 \mathrm{Ci} / \mathrm{mmol}$ ) and incubation for $90 \mathrm{~min}$ at $30^{\circ} \mathrm{C}$. Translation products were analysed by SDS-PAGE and autoradiography to demonstrate the presence of $M_{r} 65,000$ and $M_{r} 67,000$ components for GAD56 and GAD67 (Fig. 1, panel A). Typically, $5 \times 10^{6} \mathrm{cpm}$ of trichloroacetic acid precipitable radioactivity was obtained, representing $6.5 \%$ of the total radioactivity added.

\section{Radioligand binding assay}

In each analysis, $0.5 \mu$ translation mixture of ${ }^{35} \mathrm{~S}$-methionine-labelled GAD65 or GAD67, (corresponding to 50,000 cpm and $70,000 \mathrm{cpm}$ of trichloroacetic acid-precipitable material, respectively) were separately diluted to a final volume of $50 \mu \mathrm{l}$ in immunoprecipitation buffer ( $20 \mathrm{mmol} / \mathrm{l}$ Tris, $150 \mathrm{mmol} / 1 \mathrm{NaCl}, 1 \%$ Triton X-100, $0.1 \%$ aprotinin (Novo Nordisk A/S, Bagsvaerd, Denmark) and $10 \mathrm{mmol} / \mathrm{l}$ benzamidine, $(\mathrm{pH} 7.4)), 2 \mu \mathrm{l}$ (in the GAD65 antibody assay) or $4 \mu \mathrm{l}$ (in the GAD67 assay) of either human serum, ascites of a GAD65-specific monoclonal antibody (GAD6), [33] or a GAD67-specific rabbit antiserum (R9886) prepared against a synthetic heptadecapeptide representing the N-terminus of GAD67 were used per assay tube. After 60-min incubation on ice or overnight at $4{ }^{\circ} \mathrm{C}$, antibody-bounded labelled GAD was separated from free GAD using $50 \mu 150 \%$ (v/v) Protein A-Sepharose (Zymed, South San Francisco, Calif., USA) in immunoprecipitation buffer incubated for $60 \mathrm{~min}$ at $4^{\circ} \mathrm{Con}$ a rotating platform. After four washes by centrifugation in immunoprecipitation buffer (the third in immunoprecipitation buffer with $400 \mathrm{mmol} / \mathrm{l} \mathrm{NaCl}$ ), the beads were boiled in SDS sample buffer $(62.5 \mathrm{mmol} / \mathrm{l}$ Tris, $2 \%$ SDS, $10 \%$ glycerol, $\mathrm{pH} 6.8$ ) and either analysed by SDS-PAGE, and fluorography, or carefully transferred to vials for scintillation counting. The intra-assay coefficient of variation in duplicate or triplicate determinations was $11 \%$.

\section{Statistical analysis}

Antibody levels were expressed either as percent of total recombinant $\mathrm{GAD}$ radioactivity $(\mathrm{cpm})$ precipitated or as a $\mathrm{GAD}$ antibody index defined as: cpm in the unknown sample - negative standard/positive standard - negative standard. Antibody positive and negative samples were included in every assay to correct for inter-assay variation. The JDF ICA standard [34, 35], which is also GAD65 antibody positive as verified by immunoprecipitation $[2-4,12]$ was used as the GAD65 antibody positive standard. One of the 105 IDDM patients was found to be GAD67 antibody positive as verified by immunoprecipitation [12]. This serum sample was subsequently used as the positive standard in the GAD67 antibody assays. A randomly selected control serum from one of the healthy volunteers was used as the negative standard in both assays. The intra-assay coefficient of variation for duplicate and triplicate samples was 10\% for GAD65 and $15 \%$ for GAD67 antibodies. Samples considered positive based either on percent precipitated radioactivity or GAD index were confirmed by gel electrophoresis and fluorography.

The Pearson chi-square distribution analysis showed that both GAD65 and GAD67 antibody indices were not normally distributed in both test groups $(p<0.0001)$. The GAD antibody indicies were therefore analysed with the receiver-operating ROC plot [22-24] which is a powerful means to describe diagnostic accuracy (reviewed in [25]). Diagnostic accuracy is measured as diagnostic sensitivity (true positives/[true positives + false negatives]) and diagnostic specificity (true negatives/[true negatives + false positives]). The ROC plot is replac- 


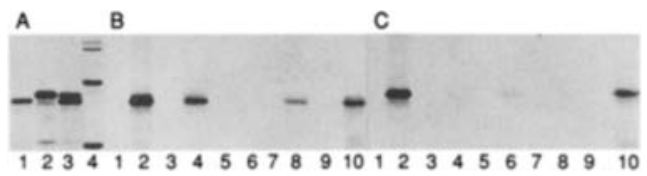

Fig. 1. SDS gel electrophoresis and autoradiography of recombinant GAD65 and GAD67 after in vitro translation and immunoprecipitation. Panel A: Analysis of in vitro translated GAD65 (lane 1), GAD67 (lane 2) and a mixture of both (lane 3). Molecular mass markers, $M_{r} 92.5 \mathrm{~K}, 69 \mathrm{~K}$ and $46 \mathrm{~K}$ are in lane 4. Panel B: Immunoprecipitation of ${ }^{35} \mathrm{~S}$-methionine-labelled recombinant GAD65 by an irrelevant IgG mouse monoclonal antibody (lane 1), the GAD65-specific monoclonal GAD-6 IgG antibody (lane 2), four sera from healthy control subjects (lanes 3, 5, 7, and 9) and IDDM patients (lane 4, 6, 8, and 10). Panel C: Immunoprecipitation of ${ }^{35} \mathrm{~S}$-methionine-labelled recombinant GAD67 by normal rabbit serum (diluted 1:100) (lane 1), the N-terminal synthetic peptide GAD67-specific rabbit antiserum (R9886) (diluted 1:100), as well as the four sera from healthy control subjects (lanes $3,5,7$, and 9) and four diabetic patients (lanes $4,6,8$, and 10 ) used in panel $\mathrm{B}$. While all controls are negative, note that diabetic serum in lane 4 is strongly positive for GAD65 but only weakly reactive with GAD67, lane 6 diabetic serum is GAD 67 but less GAD65 reactive, lane 8 is GAD 65 but not GAD67 reactive and the lane 10 serum is positive for both

ing the conventional cut-off judged by standard deviation which is applicable to normally distributed samples only - and is a graphical representation of all the sensitivity/specificity pairs to depict the overlap between the two distributions by plotting the sensitivity vs 1 - specificity for the complete range of decision thresholds [25].

Differences in levels of autoantibodies were tested with the Mann-Whitney U-test, and the Spearman rank correlation analysis was used to compare levels of different antibodies with age.

\section{Results}

\section{$G A D$ antibody radioligand binding assays}

The in vitro cDNA-directed synthesis of recombinant GAD produced stable, ${ }^{35} \mathrm{~S}$-methionine-labelled ligands which were easily and reproducibly separated from antibody-bound ligand in a single immunoabsorption step with protein A-Sepharose. SDS-PAGE and fluorography (Fig. 1), revealed that the GAD65specific monoclonal antibody GAD-6 (Fig. 1 B, lane 2) and the GAD67-specific peptide antiserum (Fig. 1C, lane 2), respectively, immunoprecipitated its relevant but not irrelevant ligand (data not shown). The validation sera in Figure 1 illustrate negative immunoprecipitates in four healthy volunteers (Fig. $1 \mathrm{~B}$ and C, lanes 3, 5, 7 and 9). Among the IDDM sera, the JDF ICA standard precipitated the recombinant GAD65 (Fig.1B, lane 4) while only weak activity was observed for recombinant GAD67 (Fig.1C, lane 4). The IDDM serum in lane 6 readily precipitated recombinant GAD67 but less recombinant GAD65, the serum in lane 8 recombinant GAD65 but not recombinant
C.E. Grubin et al.: Autoantibodies against recombinant GAD
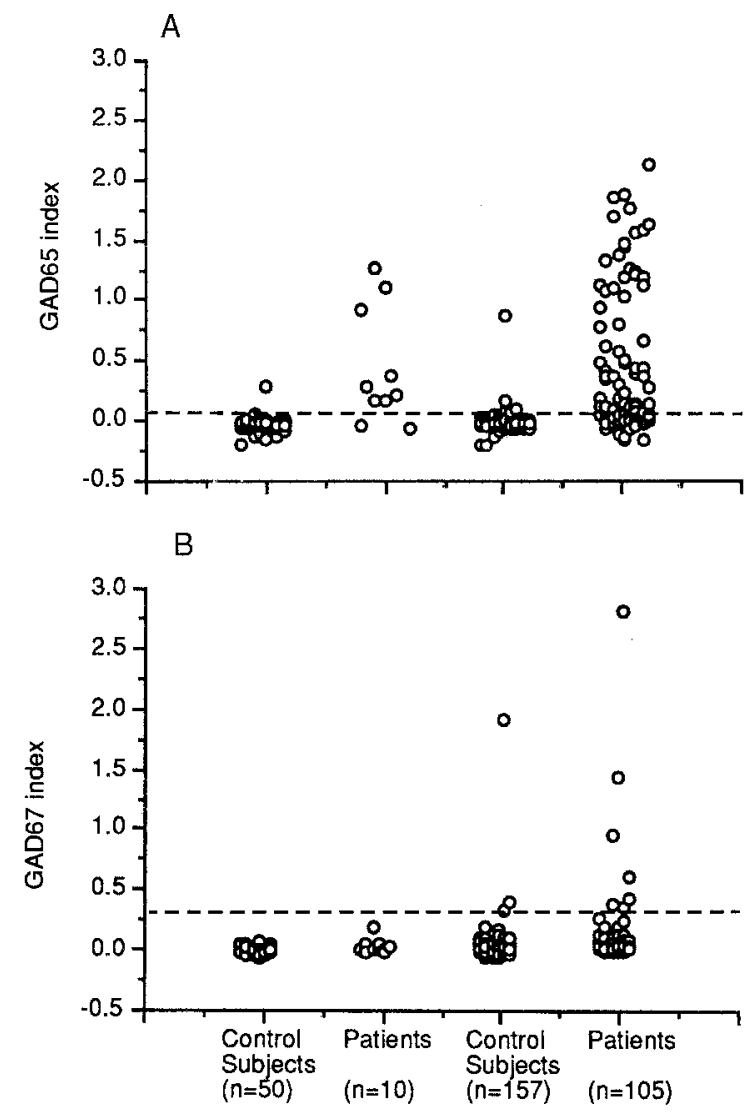

Fig. 2 A,B. Difference in recombinant $G A D$ antibody index for GAD65 (A) and GAD67 (B) in control subjects and patients with recent onset IDDM. The data in $\mathbf{A}$ show the GAD65 antibody index in the validation sera used to standardize the radioligand binding assay in healthy volunteers $(n=50)$ and ICA standard samples $(n=10)$ as well as in control children $(n=157)$ compared with recent onset diabetic patients $(n=105)$. The data in B show GAD67 antibody levels in the same serum samples. The dotted line shows the GAD index level which indicates a diagnostic specificity of $98 \%$

GAD67 while in lane 10, the serum precipitated both ligands. The IDDM serum used for validation with the highest GAD65 titre precipitated $33 \%$ of the total radioactivity at the $1: 25$ dilution which was the dilution found (in separate experiments, not shown) to obtain maximal precipitation and therefore used throughout the investigation. The GAD67 antibody standard also precipitated about $30 \%$ of the total recombinant GAD67 radioactivity; however, in the GAD67 assay optimal precipitation occurred at a 1:12.5 dilution which was used with all samples.

The 10 IDDM sera (about $2-33 \%$ of total recombinant GAD65 radioactivity was precipitated) used for validation confirmed eight positive samples (Fig. $2 \mathrm{~A}$ ). Among the 50 controls ( 48 samples precipitated less than $2 \%$, while only two samples precipitated $5 \%$ and $13 \%$, respectively of total GAD65 radioactivity) only two samples were positive (Fig.2A). In the GAD67 antibody assay only 2 of 10 diabetic samples were weakly positive $(3 \%$ and $6 \%$ precipitated and con- 

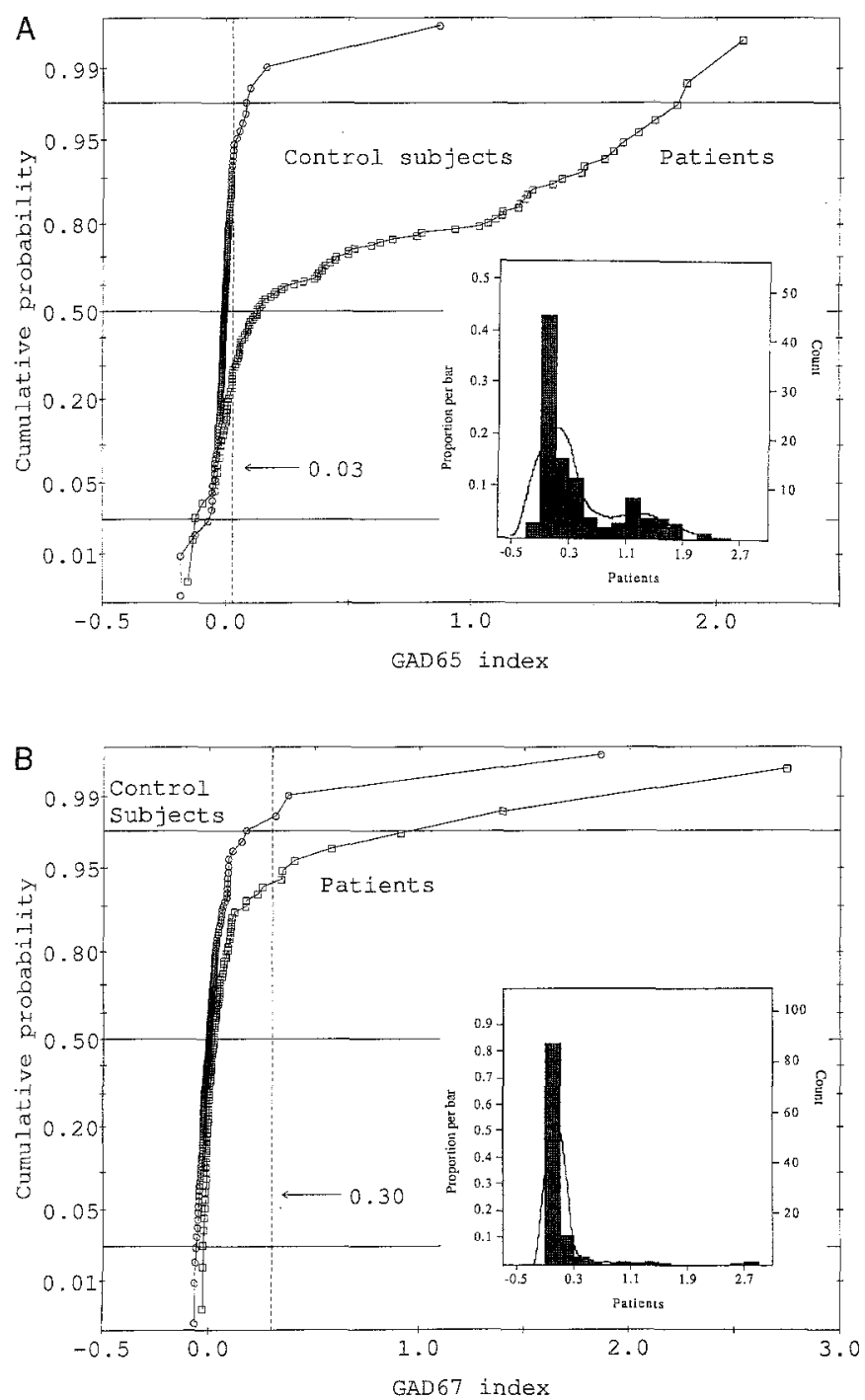

Fig.3A,B. Cumulative probability of antibodies in relation to antibody index in control children $(O, n=157)$ compared with recent onset IDDM patients $(\square, n=105)$. The data in $\mathbf{A}$ demonstrate the high frequency of sera with a elevated GAD65 index. The dotted line at a GAD65 index of 0.03 corresponds to the level where sera begin to immunoprecipiate recombinant GAD65 detected by fluorography. The insert shows the the distribution of GAD65 indicies among the patients. The data in $\mathbf{B}$ illustrate the few high GAD67 antibody index sera among both control subjects and patients. The dotted line at a GAD67 index of 0.3 corresponds to the level where sera begin to immunoprecipiate recombinant GAD67 detected by fluorography. The insert shows the distribution of GAD67 indicies among the patients

firmed by fluorography). The former sample was the JDF standard (Fig. 1C, lane 4) and the latter, one of the GAD65 antibody weak sera (Fig. 1 C, lane 6). All of the 50 validation control sera were negative for GAD67 antibodies (Fig. 2B).

The 10 IDDM validation sera, which had been kept frozen for 10 years, showed GAD65 antibody reactivity identical to our first demonstration of this antigen in human islet detergent extracts [2].

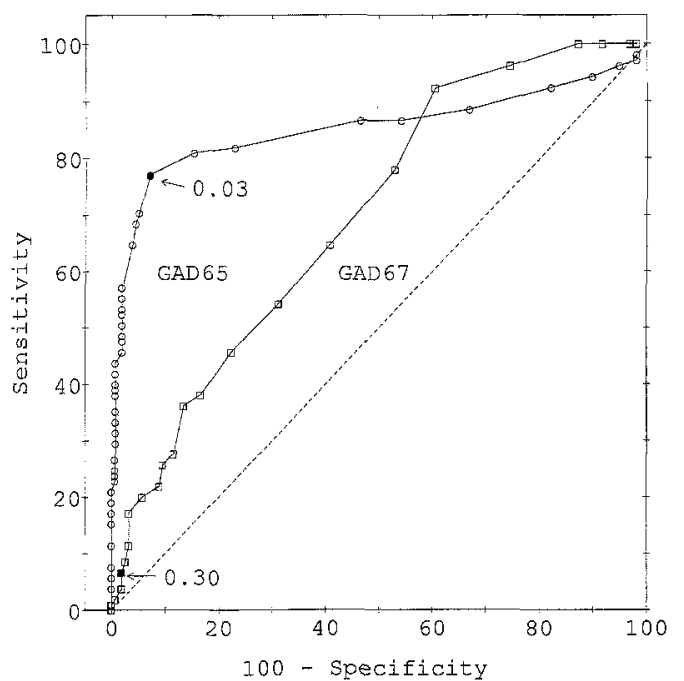

Fig.4. The ROC curve analysis of GAD65 and GAD67 antibodies. The analysis demonstrates that at a GAD65 index of 0.03 (as can be seen in Fig. $3 \mathrm{~A}$ ) the diagnostic sensitivity (positivity in disease) is $77 \%$ and diagnostic specificity (negativity in health) is $92 \%$. The GAD67 antibody test is not useful for IDDM since at a GAD67 index of 0.3 (see Fig. 3B), the diagnostic specificity is $98 \%$ but the diagnostic sensitivity only $8 \%$. While a perfect test would show a ROC plot that passes through the upper left corner, the dotted line ( $45^{\circ}$ diagonal line) represents a test with no discrimination

\section{Diagnostic sensitivity and specificity of antibodies to recombinant $G A D 65$}

The validation sera (Fig. 2) showed that 2 of 50 healthy volunteer and 8 of 10 IDDM sera had GAD65 antibodies. A GAD 65 index of 0.03 used at the cut-off. We then used the assay in a population-based study, using consecutively diagnosed IDDM children and control children.

As shown by the cumulative probability of the 105 IDDM patients and 157 control children (Fig. 3) the GAD65 antibody index was not normally distributed. Analysis of the control samples indicate that the 95th percentile in cumulative probability was reached at a GAD65 index of 0.03 (Fig. $3 \mathrm{~A}$ ). The ROC curve demonstrated that the 0.03 GAD 65 index was the most efficient accurate measurement, yielding $77 \%$ sensitivity and $92 \%$ specificity (Fig. 4 ). The ten control sera at or above the 0.03 GAD65 index cut-off were checked by fluorography which demonstrated that only 2 of 10 sera precipitated a band. The frequency of true positive controls would therefore be $2 \%$ ( 3 of 157). The median GAD65 index value in the patients was 0.13 which significantly different from -0.003 in the controls $(p<0.001)$ (Table 1$)$.

There was no correlation between GAD65 antibodies and age, sex, or ICA levels (data not shown). Levels of GAD65 antibodies and ICA in $89 \%$ (72 of $81)$ double positive patients did not correlate $(r=0.16$; $p>0.05)$. 
Table 1. Patients with IDDM and control subjects studied to compare recombinant GAD65 and GAD67 antibody reactivity

\begin{tabular}{|c|c|c|}
\hline \multirow{2}{*}{\multicolumn{3}{|c|}{$\overline{I D D M}$ (ICA standards) and healthy volunteers validation sera }} \\
\hline & & \\
\hline $\begin{array}{l}n \\
\text { Male/female ratio } \\
\text { Age (years) median (range) }\end{array}$ & $\begin{array}{l}10 \\
6 / 4 \\
12.5(10-16)\end{array}$ & $\begin{array}{l}50 \\
23 / 27 \\
27.5(20-49)\end{array}$ \\
\hline $\begin{array}{l}\text { Recombinant GAD65 antibodies: } \\
\% \text { cpm ppt; range } \\
\text { GAD65 index; median (range) } \\
\text { Antibody positivity }\end{array}$ & $\begin{array}{l}2-33 \% \\
0.25(-0.046-1.3) \\
8 / 10\end{array}$ & $\begin{array}{l}1-13 \% \\
-0.016(-0.19-0.30) \\
2 / 50\end{array}$ \\
\hline $\begin{array}{l}\text { Recombinant GAD67 antibodies: } \\
\text { \% cpm ppt; range } \\
\text { GAD67 index; median (range) } \\
\text { Antibody positivity }\end{array}$ & $\begin{array}{l}1-6 \% \\
-0.0002(-0.024-0.17) \\
2 / 10\end{array}$ & $\begin{array}{l}1-3 \% \\
-0.0064(-0.060-0.066) \\
0 / 50\end{array}$ \\
\hline Recent onset IDDM children and matched cor & & \\
\hline $\begin{array}{l}n \\
\text { Male/female ratio } \\
\text { Age (years) median (range) } \\
\text { Duration of IDDM in days: median (range) }\end{array}$ & $\begin{array}{l}105 \\
56 / 49 \\
10(0-14) \\
1(0-64)\end{array}$ & $\begin{array}{l}157 \\
80 / 77 \\
10(0-14) \\
\text { N/A }\end{array}$ \\
\hline $\begin{array}{l}\text { Recombinant GAD65 antibodies: } \\
\% \text { cpm ppt; range } \\
\text { GAD65 index: median (range) } \\
\text { Antibody positivity (\%) }\end{array}$ & $\begin{array}{l}1-54 \% \\
0.13(-0.15-2.11) \\
81 / 105(77 \%)\end{array}$ & $\begin{array}{l}1-15 \% \\
-0.003(-0.18-0.87) \\
3 / 157(2 \%)\end{array}$ \\
\hline $\begin{array}{l}\text { Recombinant GAD67 antibodies: } \\
\% \text { cpm ppt; range } \\
\text { GAD67 index: median (range) } \\
\text { Antibody positivity (\%) }\end{array}$ & $\begin{array}{l}1-72 \% \\
0.027(-0.026-2.75) \\
8 / 105(8 \%)\end{array}$ & $\begin{array}{l}1-36 \% \\
0.002(-0.064-1.87) \\
3 / 157(2 \%)\end{array}$ \\
\hline $\begin{array}{l}\text { ICA: } \\
\text { JDF Units: median (range) } \\
\text { Frequency of positive samples (\%) }\end{array}$ & $\begin{array}{l}30(0-5520) \\
92 / 105(88 \%)\end{array}$ & $\begin{array}{l}265(30-410) \\
3 / 157(2 \%)\end{array}$ \\
\hline $\begin{array}{l}\text { Antibody concordance rates: } \\
\text { GAD65 and GAD67 } \\
\text { GAD65 and ICA } \\
\text { GAD67 and ICA }\end{array}$ & $\begin{array}{l}6 / 81(7 \%) \\
72 / 81(89 \%) \\
8 / 8(100 \%)\end{array}$ & $\begin{array}{l}2 / 3 \\
1 / 3 \\
1 / 3\end{array}$ \\
\hline
\end{tabular}

cpm ppt is radioactivity precipitated of total trichloroacetic acid precipitable radioactivity added in each assay tube

\section{Diagnostic sensitivity and specificity of antibodies to recombinant $G A D 67$}

The GAD67 radioligand binding assay revealed only two weakly positive samples among the IDDM but none of the control validation sera (Fig. 2B). Analysis of the 157 control and 105 IDDM sera revealed equally low frequencies of positive sera (Fig. 2B). Since the two IDDM validation sera with low level GAD67 antibodies were not useful, we selected one of the GAD67 antibody positive patient samples as a positive control and re-analysed all samples to calculate the GAD67 antibody index (Table 1). The cumulative distribution of the GAD67 index, showed that patients deviated minimally from the control curve (Fig. 3B). The ROC curve indicated that the most efficient GAD67 index cut-off was 0.3 . At this index, the sensitivity of GAD67 antibodies for IDDM is only $8 \%$ ( 8 of 105) and the specificity $98 \%$ (154 of 157). The median GAD67 antibody index was 0.027 among the patients which was different from 0.002 among the control subjects $(p<0.003)$. The eight GAD67 antibody positive patients precipitated a $M_{r} 67,000$ band and six of eight were also positive both for GAD65 antibodies and for ICA. One of the GAD67 antibody positive healthy controls also had GAD65 antibodies as well as ICA, and this individual developed IDDM 8 months after the sample was obtained [31].

\section{Discussion}

The same 10 IDDM sera used in the present study to validate our novel radioligand binding assays with recombinant GAD, were also those used in the first study to demonstrate the $64 \mathrm{~K}$ human islet antigen [2] recently identified as GAD [6]. Subsequent molecular cloning showed human islet GAD [7] to represent GAD65, a novel isoform different from the previously identified GAD67 $[8,10,36]$. The availability of cDNA sequences for human islet [7] and brain [8] GAD65 enabled their amino acid sequence comparison and showed these to 
be identical. The present study supports previous demonstrations that the GAD65 mRNA [7] codes for the $64 \mathrm{~K}$ antigen $[12,21,37]$. The results of this study also confirm other studies $[12,18,20]$ but fail to support investigations showing that IDDM sera have significant reactivity to GAD67 [13] or GAD67 peptide fragments [16]. This discrepancy remains to be explained but may be due to the formation of GAD65/GAD67 heterodimers [38] in extracts of brain or rat islet [14] or recombinant mixtures which contain both isoforms. A distinct advantage of the present assays is the use of a radioligand which is translated from the transcript of the cDNA genes for GAD. The assay type may also be critical. Our cDNA directed in vitro-synthesized proteins retain full antibody reactivity not only with IDDM sera but also with the GAD65 monoclonal antibody (GAD-6) and our own GAD67-specific N-terminal synthetic peptide antiserum. However, it cannot be assumed that recombinant GAD or GAD fragments will yield the same information when adsorbed to plates for ELISA. The present assay is a liquid phase radioimmunoassay which allows the ligand to remain in solution and also alleviates the cumbersome SDSPAGE analysis of numerous samples. It is possible that IDDM antibodies recognize a subtle tertiary polypeptide structure as the vast majority of IDDM sera are not reactive on immunoblots containing either native [6] or recombinant [21] GAD65. The present study also suggests that the recombinant GAD65 and GAD67 produced by in vitro translation is sufficiently folded and that little or no post-translational modifications are necessary for IDDM serum reactivity.

The present analysis has implications for studies on the prediction of IDDM using GAD antibody assays. Our GAD65 and GAD67 antibody assays allow the diagnostic accuracy (for review see [25]), i.e. sensitivity and specificity to be defined in attempts to predict IDDM in the general population. Large population screenings have been initiated; however, there are several complicating factors. First, although certain HLA alleles such as DQB1*0302-DQA1*0301(DQ8)-DR4 DQB1*0201-DQA1*0501(DQ2)-DR3 are found among more than $90 \%$ of IDDM children (sensitivity is high), about $50 \%$ of the healthy population are positive for these alleles (poor specificity). Second, ICA and insulin autoantibodies, alone or in combination show $88 \%$ sensitivity and $96 \%$ specificity, but the predictive value of finding a child with the disease was only $3 \%$ since the prevalence rate is as low as $0.15 \%$ [39]. Third, not all ICA, insulin autoantibodies or GAD antibody-positive individuals (such as healthy first degree relatives) progress to diabetes [40]. Fourth, the frequency of ICA (2-4\%), insulin autoantibodies (1$2 \%$ ) and now GAD 65 antibodies ( $2 \%$ ) among healthy schoolchildren exceeds the prevalence of the disease by a factor of 10-20. This discrepancy between marker positivity and clinical onset may be explained by GAD antibodies that develop irrespective of the HLA type and that conversion from marker positivity to disease onset requires the presence of susceptible HLA alleles. The availability of the present simple, precise and reproducible radioligand recombinant $\mathrm{GAD}$ antibody binding assays suitable for small blood samples, (2$4 \mu \mathrm{l}$ ) will make it possible to identify GAD antibodypositive individuals and factors which determine progression to or protection from IDDM.

Acknowledgements. The authors are indebted to Ms. S. Blaylock and Ms. B.Persson for assistance. This work was supported by grants from the National Institutes of Health (DK26190, DK33873, DK41801), the Juvenile Diabetes Foundation International, the Swedish Medical Research Council, the Swedish Diabetes Association, The Nordisk Insulin Foundation and the Hoechst Medical Research Foundation. WAH is a Howard Hughes Medical Institute Physician Fellow and AEK is supported by the Juvenile Diabetes Foundation International.

\section{References}

1. Lernmark $\AA$, Baekkeskov S (1981) Islet cell antibodiestheoretical and practical implications. Diabetologia 21: 431-435

2. Baekkeskov S, Nielsen JH, Marner B, Bilde T, Ludvigsson J, Lernmark $\AA$ (1982) Autoantibodies in newly diagnosed diabetic children immunoprecipitate human pancreatic islet cell proteins. Nature 298: 167-169

3. Christie M, Landin-Olsson M, Sundkvist G, Dahlquist G, Lernmark $\AA$, Baekkeskov $S(1988)$ Antibodies to a $M_{r} 64,000$ islet cell protein in Swedish children with newly diagnosed type 1 (insulin-dependent) diabetes. Diabetologia 31: 597602

4. Baekkeskov S, Landin-Olsson M, Kristensen JK et al. (1987) Antibodies to a $M_{r} 64,000$ human islet cell antigen precede the clinical onset of insulin-dependent diabetes. J Clin Invest 79: 926-934

5. Atkinson MA, Maclaren NK, Scharp DW, Lacy PE, Riley WJ (1990) 64,000 $\mathrm{M}_{r}$ autoantibodies as predictors of insulindependent diabetes. Lancet 335: 1357-1360

6. Baekkeskov S, Aanstoot HJ, Christgau S et al. (1990) Identification of the $64 \mathrm{~K}$ autoantigen in insulin-dependent diabetes as the GABA-synthesizing enzyme glutamic acid decarboxylase 347: 151-156

7. Karlsen AE, Hagopian WA, Grubin CE et al. (1991) Cloning and primary structure of a human islet isoform of glutamic acid decarboxylase from chromosome 10. Proc Natl Acad Sci USA 88: 8337-8341

8. Bu D-F, Erlander MG, Hitz BC et al. (1992) Two human glutamate decarboxylases, 65-kDa GAD and 67-kDa GAD, are each encoded by a single gene. Proc Natl Acad Sci USA 89: 2115-2119

9. Sparkes RS, Kaufman DL, Heinzmann C, Tobin AJ, Mohandas T (1987) Brain glutamate decarboxylase (GAD) gene assigned to human chromosome 2 by somatic cell hybrid analysis. Cytogenet Cell Genet 46: 696

10. Michelsen BK, Petersen JS, Boel E, Møldrup A, Dyrberg T, Madsen OD (1991) Cloning, characterization, and autoimmune recognition of rat islet glutamic acid decarboxylase in insulin-dependent mellitus. Proc Natl Acad Sci USA 88: 8754-8758

11. Karlsen AE, Michaelsen BK, Pedersen JK et al. (1992) Glutamic acid decarboxylase: an autoantigen in insulin-dependent diabetes mellitus. Diabetes Nutr Metab 5: 97-103 
12. Hagopian WA, Michelsen B, Karlsen AE et al. (1993) Autoantibodies in IDDM primarily recognize the $65,000-\mathrm{M}_{\mathrm{r}}$ rather than the $67,000-\mathrm{M}_{\mathrm{r}}$ isoform of glutamic acid decarboxylase. Diabetes 42: 631-636

13. Kaufman DJ, Erlander MG, Clare-Salzer M, Atkinson MA, Maclaren NK, Tobin AJ (1992) Autoimmunity to two forms of glutamate decarboxylase in insulin-dependent diabetes mellitus. J Clin Invest 89: 283-292

14. Petersen JB, Russel S, Marshall MO et al. (1993) Differential expression of glutamic acid decarboxylase in rat and human islets. Diabetes 42: 484-495

15. Rowley MJ, Mackay JR, Chen Q-Y, Knowles WJ, Zimmet PZ (1992) Antibodies to glutamic acid decarboxylase discriminate major types of diabetes mellitus. Diabetes 41:548551

16. De Aizpurua HJ, Harrison LC, Cram DS (1992) An ELISA for antibodies to recombinant glutamic acid decarboxylase in IDDM. Diabetes 41: 1182-1187

17. Atkinson M, Kaufman D, Newman D, Tobin A, Maclaren N (1993) Islet cell cytoplasmic autoantibody reactivity to glutamate decarboxylase in insulin-dependent diabetes. J Clin Invest $91: 350-356$

18. Velloso LA, Kämpe O, Hallberg A, Christmanson L, Betsholtz C, Karlsson FA (1993) Demonstration of GAD-65 as the main immunogenic isoform of glutamate decarboxylase in type 1 diabetes and determination of autoantibodies using a radioligand produced by eukaryotic expression. J Clin Invest 91: 2084-2090

19. Martino G, Tappaz M, Braghi S et al. (1991) Autoantibodies to glutamic acid decarboxylase (GAD) detected by an immunotrapping enzyme activity assay: relation to insulin dependent diabetes mellitus and islet cell antibodies. J Autoimmunity 4: 915-923

20. Seissler J, Amann J, Mauch L et al. (1993) Prevalence of autoantibodies to the 65 - and $67-\mathrm{kD}$ isoforms of glutamate decarboxylase in insulin-dependent diabetes mellitus. J Clin Invest 92: 1394-1399

21. Karlsen AE, Hagopian WA, Petersen JS et al. (1992) Recombinant glutamic acid decarboxylase representing a single isoform expressed in human islets detects IDDM association 65K autoantibodies. Diabetes 41: 1355-1359

22. Yang KL, Tobin MJ (1991) A prospective study of indexes redicting the outcome of trials of weaning from mechanical ventilation. N Engl J Med 324: 1145-1450

23. Metz CE (1978) Basic principle of ROC analysis. Semin Nucl Med 8: 283-298

24. Christou NV, Tellado-Rodriguez J, Chartrand L et al. (1989) Estimating mortality risk in preoperative patients using immunologic, nutritional, and acute-phase response variables. Ann Surg 210: 69-77

25. Zweig M, Campbell G (1993) Receiver-operating characteristics (ROC) plots: a fundamental tool in clinical medicine. Clin Chem 39: 561-577

26. Ludvigsson J, Heding L, Liedén G, Marner B, Lernmark Å (1983) Plasmapheresis in the initial treatment of insulin-dependent diabetes mellitus in children. BMJ 286: 176-178

27. Marner B, Lernmark Å, Ludvigsson J et al. (1985) Islet cell antibodies in insulin-dependent (type 1) diabetic children treated with plasmapheresis. Diabetes Res 2:231-236
28. Bonifacio E, Dawkins RL, Lernmark $\AA$ (1987) Immunology and diabetes workshops: report of the second international workshop on the standardization of cytoplasmic islet cell antibodies. Diabetologia 30: 273

29. Bottazzo GF, Gleichmann H (1986) Immunology and diabetes workshops: report of the first international workshop on the standardisation of cytoplasmic islet cell antibodies. Diabetologia 29: 125-126

30. Landin-Olsson M, Sundkvist G, Lernmark A (1987) Prolonged incubation in the two-colour immunofluorescence test increases the prevalence and titres of islet cell antibodies in type 1 (insulin-dependent) diabetes mellitus. Diabetologia $30: 327-332$

31. Landin-Olsson M, Karlsson A, Dahlquist G, Blom L, Lernmark $\AA$, Sundkvist G (1989) Islet cell and other organ-specific autoantibodies in all children developing type 1 (insulindependent) diabetes mellitus in Sweden during one year and in matched controls. Diabetologia 32: 387-395

32. Dahlquist G, Blom L, Tuvemo T, Nyström L, Sandström A, Wall S (1989) The Swedish childhood diabetes study -results from a nine year case register and one year case-referent study indicating that type 1 (insulin-dependent) diabetes mellitus is associated with both type 2 (non-insulin-dependent) diabetes mellitus and autoimmune disorders. Diabetologia 32: 2-6

33. Gottlieb DI, Chang Y-C, Schwob JE (1986) Monoclonal antibodies to glutamic acid decarboxylase. Proc Natl Acad Sci USA 83: 8808-8812

34. Bonifacio E, Lernmark Å, Dawkins RL (1988) Serum exchange and use of dilutions have improved precision of measurement of islet cell antibodies. J Immunol Methods 106: $83-88$

35. Lernmark $\AA$, Molenaar JL, van Beers WAM et al. (1991) The Fourth International Serum Exchange Workshop to standardize cytoplasmic islet cell antibodies. Diabetologia 34: 534-535

36. Erlander MG, Tillakaratne NJK, Feldblum S, Patel N, Tobin AJ (1991) Two genes encode distinct glutamate decarboxylase. Neuron 7: 91-100

37. Hagopian WA, Karlsen AE, Gottsäter A et al. (1993) Quantitative assay using recombinant human islet glutamic acid decarboxylase (GAD65) shows 64K autoantibody positivity at onset predicts diabetes type. J Clin Invest 91:368-374

38. Christgau S, Schierbeck H, Aanstoot H-J et al. (1991) Pancreatic $\beta$ cells express two autoantigenic forms of glutamic acid decarboxylase, a $65-\mathrm{kDa}$ hydrophilic form and a $64-\mathrm{kDa}$ amphiphilic form which can be both membrane-bound and soluble. J Biol Chem 286: 21257-21264

39. Landin-Olsson M, Palmer JP, Lernmark $\AA$ et al. (1992) Predictive value of islet cell and insulin autoantibodies for type 1 (insulin-dependent) diabetes mellitus in a population-based study of newly diagnosed diabetic and matched control children. Diabetologia 35: 1068-1073

40. Bärmeier H, McCulloch DK, Neifing JL et al. (1991) Risk for developing type 1 (insulin-dependent) diabetes mellitus and the presence of islet 64K antibodies. Diabetologia 34: 727733 